\title{
Faktor Pengaruh Kualitas Pelayanan, Harga dan Kepuasan Turis Di Tanjung Lesung Provinsi Banten
}

\author{
Soehardi ${ }^{1, *}$ \\ ${ }^{1}$ Fakultas Ekonomi dan Bisnis, Universitas Bhayangkara Jakarta Raya; Jl. Raya \\ Perjuangan, Marga Mulya, Bekasi Utara, Jawa Barat 17121; Telp.021-88955882, \\ 889955883, e-mail: soehardi@dsn.ubharajaya.ac.id \\ * Korespondensi: e-mail: soehardi@dsn.ubharajaya.ac.id \\ Submitted: 27/03/2021; Revised: 05/04/2021; Accepted: 11/05/2021; Published: 27/05/2021
}

\begin{abstract}
The purpose of this study was to analyze the factors of service quality, price and satisfaction of foreign and domestic tourists in the Special Economic Zone of Tanjung Lesung, Pandeglang Municipality, Banten Province. The population consisted of foreign and domestic tourists visiting Tanjung Lesung, while the sample used was accidental sampling, with a total of 140 respondents. The quantitative research method used in this study was the analysis of validity, reliability, $t$ test, $F$ test and $R$ square tests with SPSS software. Service quality has a significant effect on tourist satisfaction in the Special Economic Zone of Tanjung Lesung, Pandeglang Municipality, Banten Province. Tourist attractiveness as the main indicator of service quality compared to other indicators such as destination facilities and accessibility to tourist destinations. Price has a significant effect on tourist satisfaction in the Special Economic Zone of Tanjung Lesung, Pandeglang Municipality, Banten Province. Hotel room prices are the main indicator compared to other indicators such as food and beverages prices, sports equipment rental prices and professional fees for tour guides. Service quality and price together have a significant effect on tourist satisfaction in the Special Economic Zone of Tanjung Lesung, Pandeglang Municipality, Banten Province. The natural scenery of the white sand beach resort with a background of sea waves and the Child of Mount Krakatau is the main indicator of tourist satisfaction compared to other indicators such as several tourist visits, security and safety as well as cleanliness and hygiene.
\end{abstract}

Keywords: Price and Tourist Satisfaction, Service Quality, Service Quality Factor

\begin{abstract}
Abstrak
Tujuan penelitian ini adalah untuk menganalisa faktor-faktor kualitas pelayanan, harga dan kepuasan Turis asing dan nusantara di Kawasan Ekonomi Khusus Tanjung Lesung Kabupaten Pandeglang Provinsi Banten. Populasi adalah Turis asing dan nusantara yang berkunjung di Tanjung Lesung, sedangkan sampel yang digunakan adalah accidental sampling diperoleh responden berjumlah 140. Metode penelitian kuantitatif digunakan dalam penelitian ini dengan analisis uji validitas, reliabilitas, uji t, uji $\mathrm{F}$ dan $\mathrm{R}$ square dengan software SPSS. Kualitas pelayanan berpengaruh secara signifikan terhadap kepuasan Turis di Kawasan Ekonomi Khusus Tanjung Lesung Kabupaten Pandeglang Provinsi banten. Daya tarik wisata sebagai indikator utama kualitas pelayanan dibandingkan indikator lainnya seperti fasilitas destinasi dan akksesibilitas menuju destinasi wisata. Harga berpengaruh secara signifikan terhadap kepuasan Turis di Kawasan Ekonomi Khusus Tanjung Lesung Kabupaten Pandeglang Provinsi banten. Harga kamar hotel sebagai indikator utama dibandingkan indikator lainnya seperti harga food and beverages, harga sewa kelengkapan olahraga dan professional fee for tour guide. Kualitas pelayanan dan harga sevara bersama-sama berpengaruh secara signifikan terhadap kepuasan Turis di Kawasan Ekonomi Khusus Tanjung Lesung Kabupaten Pandeglang Provinsi Banten. Pemandangan alam resor pantai pasir putih dengan latar belakang gelombang laut dan Anak Gunung Krakatau merupakan
\end{abstract}


indikator utama kepuasan Turis dibandingkan indikator lainnya seperti beberapa kali kunjungan Turis, keamanan dan keselamatan serta kebersihan dan hygiene.

Kata kunci: Harga dan Kepuasan Turis, Kualitas Pelayanan, Faktor Kualitas Pelayanan

\section{Pendahuluan}

Kementerian Pariwisata dan Ekonomi Kreatif telah mengumumkan dan menetapkan bahwa Tanjung Lesung sebagai salah daerah destinasi wisata di Indonesia tahun 2018. Hal ini sesuai dengan Peraturan Pemerintah Republik Indonesia Nomor 26 Tahun 2012 yang telah ditetapkan Tanjung Lesung sebagai Kawasan Ekonomi Khusus seluas 1.500 hektar terletak di Kecamatan Panimbang Kabupaten Pandeglang Provinsi Banten (Pemerintah Republik Indonesia, 2012). Penduduk kabuaten ini berjulah 1,28 juta jiwa. Jarak tempuh $\pm 160 \mathrm{~km}$ dari lokasi Tanjung Lesung ke DKI Jakarta atau \pm 3 jam perjalanan dengan menggunakan transportasi darat.

Wisatawan asing dan nusantara yang berkunjung ke Kabupaten Pandeglang Provinsi Banten tahun 2018 berjumlah 3.105.051 orang dengan perincian wisatawan asing berjumlah 3.102.472 dan wisatawan domestic berjumlah 2.579 orang (Dinas Pariwisata Kabupaten Pandeglang, 2020). Wisatawan yang berkunjung ke Kabupaten Pandeglang tahun 2019 berjumlah 2,4 juta orang dan bulan Januari hingga September 2020 berjumlah 480.000 orang. Sedangkan penginapan seperti hotel bintang dan non bintang di Kabupaten Pandeglang tahun 2018 berjumlah 168 dan restoran berjumlah 38 .

Salah satu daya tarik banyaknya wisatawan asing dan nusantara berkunjung ke Tanjung Lesung adalah kelancaran dan kemudahan aksesabilitas dengan telah semakin membaiknya pembangunan infrastruktur dari mulai Kota Cilegon dan Kota Serang menuju sepanjang pantai Anyer, Carita, Panimbangan, Tanjung Lesung hingga Taman Nasional Ujung Kulon. Daya tarik Tanjung Lesung lainnya adalah pasir putih kawasan wisata pantai yang indah, alami dan bersih dengan latar belakang menikmati pemandangan gunung Krakatau dengan mengabadikan matahari terbenam perlahan-lahan serta tebing-tebing berbentuk curam atau lesung. Berbagia kegiatan untuk menarik wisatawan asing dan nusantara antara lain: snorkeling, diving, fishing and banana boat.

Pembangunan infrastruktur dengan penerangan ramah lingkungan panel surya ini berdampak pada semakin meningkatnya pertumbuhan ekonomi, semakin bertambahnya lapangan pekerja dan semakin meningkatnya pula pendapatan masyarakat di Tanjung Lesung dan sekitarnya. Hal ini dapat dilihat langsung di lapangan semakin banyaknya investor asing dan domestik menanamkan modalnya sedang giat-gitanya melaksanakan pembangunan industri pariwisata seperti hotel bintang dan non bintang serta mulai tumbuhnya usaha mikro, kecil dan menengah.

Beberapa permasalahan-permasalahan yang sedang dihadapi di Kawasan Ekonomi Khusus Tanjung Lesung diantaranya: kurangnya kualitas pelayanan karyawan seperti sebagian besar karyawan belum memiliki sertifikasi kompetensi di bidang pariwisata, kurangnya 
kebersihan dan hygiene comfort room, jaringan internet yang tidak stabil serta persaingan harga yang semakin ketat. Ketatnya persaingan harga yang dilakukan oleh para pemilik usaha tempat-tempat penginapan di Tanjung Lesung dalam memasarkan promosi produk dan jasanya untuk menarik wisatawan mancanegara dan nusantara dapat dilihat dari website agoda.com, tripadvisor, booking.com, traveloka dan lain-lain.

\subsection{Wisata Resor Pantai}

Salah satu jenis pariwisata yang paling populer dalam skala global dan merupakan kunci penggerak ekonomi utama untuk daerah tujuan wisata dikenal dengan nama wisata pantai (Alves et al., 2014). Lokasi rekreasi utama yang dapat menarik seseorang ke air dan oleh karena itu mempengaruhi bisnis ke tempat-tempat lain disekitarnya (Amyot \& Grant, 2014).

Wisata pantai atau dikenal juga dengan wisata bahari adalah lokasi wisata yang memanfaatkan sumber daya alam pantai untuk menarik kunjungan wisatawan asing dan nusantara yang melakukan kegiatan rekreasi dan bisnis serta berdampak bergeraknya ekonomi masyarakat ke tempat-tempat lain disekitarnya.

\subsection{Kualitas Pelayanan}

Kualitas pelayanan berdasarkan kepuasan wisatawan mancanegara dan nusantara di destinasi wisata adalah aksesibilitas destinasi, fasilitas destinasi dan daya tarik destinasi. Fasilitas terdiri dari: restoran, souvenir dan tour guide (Al-Ababneh, 2013). Aksesibilitasterdiri dari: peta, parking dan toilet. Sedangkan daya tarik wisata adalah museum. (Hau \& Omar, 2014), kualitas pelayanan di industry pariwisata terdiri dari: citra destinasi, pelayanan penunjang dan keamanan destinasi, kebersihan destinasi dan fasilitas destinasi.

\subsection{Harga}

Penetapan harga suatu produk atau jasa bertujuan untuk memaksimalkan keuntungan perusahaan. Penetapan harga ini memiliki hubungan antara biaya, tingkat persaingan dan permintaan. Harga bauran produk terdiri dari: harga lini produk, harga fitur opsional, harga captive-product, harga dua bagian, harga produk sampingan, dan harga bundling produk (Kotler \& Keller, 2016). Harga merupakan salah satu pertimbangan wisatawan asing dan domestic berkunjung ke daerah tujuan wisata. Beberapa indicator harga antara lain: jarak tempuh menuju daerah tujuan wisata dan berapa lama yang dibutuhkan untuk menginap (Aliman et al., 2016).

\subsection{Kepuasan Wisatawan}

Kualitas pelayanan meliputi akomodasi, hospitality, fasilitas turis, food and beverage, hygiene, harga dan nilai, perjamuan, kenyamanan, komunikasi, keamanan, transportasi, cuaca dan loyalitas wisatawan. Kepuasan wisatawan juga dapat dilihat dari keinginan untuk berkunjung kembali ke destinasi wisata dan keinginan memberikan rekomendasi untuk meningkatkan kepuasan wisatawan (Rahman et al., 2011). Indicator kepuasan wisatawan asing dan nusantara adalah senang berkunjung, menyukai destinasi wisata, perasaan positif destinasi wisata dan menambah pengalaman (Aliman et al., 2016). 


\section{Metode Penelitian}

Populasi adalah wisatawan asing dan domestik yang berkunjung di Tanjung Lesung, sedangkan sampel yang digunakan adalah accidental sampling diperoleh responden berjumlah 140. Metode penelitian kuantitatif digunakan dalam penelitian ini dengan analisis uji validitas, reliabilitas, uji t, uji F dan R square dengan software SPSS.

\section{Hasil Penelitian}

Karakteristik dari responden di Tanjung Lesung yang digunakan beberapa jenis variabel dan kategori seperti ditunjukkan pada Tabel 1.

Tabel 1. Karakteristik Responden di Tanjung Lesung

\begin{tabular}{|c|c|c|c|}
\hline Variabel & Kategori & Frekuensi & Persentase \\
\hline \multirow[t]{2}{*}{ Jenis Kelamin } & Laki-Laki & 53 & $37,86 \%$ \\
\hline & Perempuan & 87 & $62,14 \%$ \\
\hline \multirow[t]{3}{*}{ Umur } & $\leq 25$ tahun & 49 & $35,00 \%$ \\
\hline & $25-50$ tahun & 62 & $44,29 \%$ \\
\hline & $\geq 50$ tahun & 29 & $20,71 \%$ \\
\hline \multirow[t]{3}{*}{ Pekerjaan } & Pegawai Pemerintah & 32 & $22,86 \%$ \\
\hline & Pegawai Swasta & 97 & $69,29 \%$ \\
\hline & Belum Bekerja & 11 & $7,85 \%$ \\
\hline \multirow[t]{3}{*}{ Pendidikan } & SD, SMP dan SMA & 78 & 55,71 \\
\hline & Diploma dan Sarjana & 47 & 33,58 \\
\hline & Masteral dan Doktoral & 15 & 10,71 \\
\hline \multirow[t]{3}{*}{ Pendapatan per Bulan } & $\leq 5$ Juta & 14 & $10,00 \%$ \\
\hline & $5-10$ Juta & 79 & $56,43 \%$ \\
\hline & $\geq 10$ Juta & 47 & $33,57 \%$ \\
\hline \multirow[t]{2}{*}{ Kewarganegaraan } & WNI & 117 & $83,57 \%$ \\
\hline & WNA & 23 & $16,43 \%$ \\
\hline \multirow[t]{2}{*}{ Akomodasi } & Hotel Bintang & 46 & $32,86 \%$ \\
\hline & Hotel Non-Bintang & 94 & $67,14 \%$ \\
\hline \multirow[t]{3}{*}{ Tujuan berkunjung } & Rekreasi & 68 & $48,57 \%$ \\
\hline & Bisnis & 56 & $40,00 \%$ \\
\hline & Kunjungan Keluarga dan Teman & 16 & $11,43 \%$ \\
\hline \multirow{4}{*}{$\begin{array}{c}\text { Kemungkinan untuk Kembali } \\
\text { Lagi ke Tanjung Lesung }\end{array}$} & Kembali untuk kedua kalinya & 68 & $48,57 \%$ \\
\hline & & & \\
\hline & Kembali untuk ketiga kalinya & 53 & $37,86 \%$ \\
\hline & Tidak akan kembali & 19 & 13,57 \\
\hline
\end{tabular}

Sumber: Hasil Pengolahan Data (2020)

Berdasarkan tabel 2 dan 3 pada uji validitas dan reliabilitas kualitas pelayanan (X1), diperoleh data bahwa seluruh item nomor 1, 2, 3, 4 dan 5 adalah valid. Begitu pula pada uji reliabilitas, diperoleh data bahwa seluruh item nomor 1, 2, 3, 4 dan 5 adalah reliable atau konsisten. Pada Tabel 2 menjelaskan uji validitas kualitas pelayanan (X1) 
Tabel 2. Uji Validitas Kualitas Pelayanan (X1)

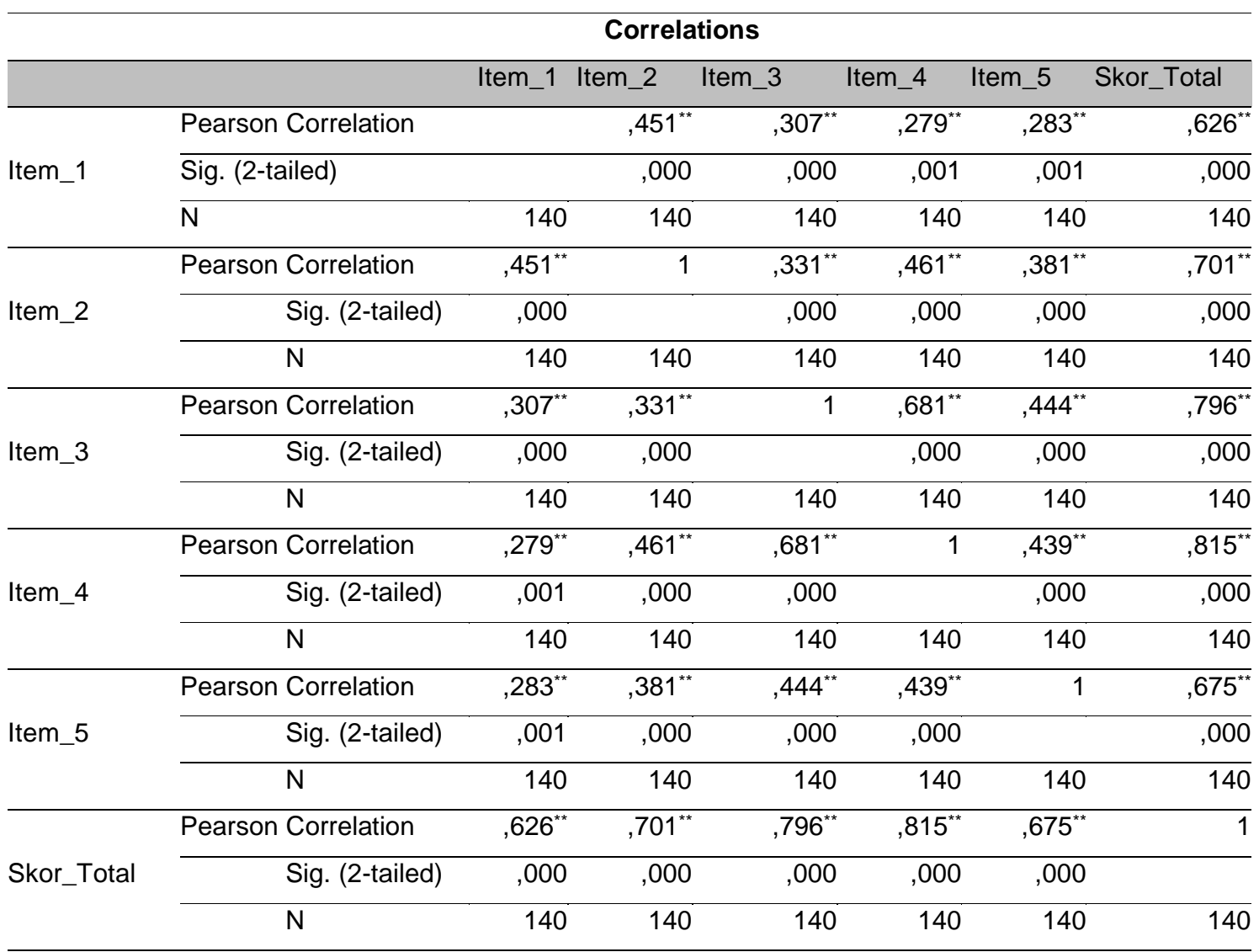

**. Correlation is significant at the 0.01 level (2-tailed).

Sumber: Hasil Pengolahan Data (2020)

Tabel 3 menjelaskan uji reliabilitas dari kualitas pelayanan pada setiap item yang digunakan pada penelitian ini.

Tabel 3. Uji Reliabilitas Kualitas Pelayanan

\begin{tabular}{|c|c|c|c|c|}
\hline \multicolumn{5}{|c|}{ Item-Total Statistics } \\
\hline & $\begin{array}{l}\text { Scale Mean i } \\
\text { Item Deleted }\end{array}$ & $\begin{array}{l}\text { ifScale Variance } \\
\text { Item Deleted }\end{array}$ & $\begin{array}{l}\text { ifCorrected Iter } \\
\text { Total Correlation }\end{array}$ & $\begin{array}{l}\text {-Cronbach's Alpha if } \\
\text { Item Deleted }\end{array}$ \\
\hline Item_1 & 16,24 & 3,879 & ,419 & ,772 \\
\hline Item_2 & 16,14 & 3,773 & ,539 & ,735 \\
\hline Item_3 & 16,32 & 3,112 & ,617 & ,706 \\
\hline Item_4 & 16,46 & 3,113 & ,658 & ,689 \\
\hline Item_5 & 15,91 & 3,912 &, 518 & ,743 \\
\hline
\end{tabular}

Sumber: Hasil Pengolahan Data (2020)

Berdasarkan tabel 4 dan 5 pada uji validitas dan reliabilitas tentang harga (X2), diperoleh data bahwa seluruh item nomor 1, 2, 3, 4 dan 5 adalah valid. Begitu pula pada uji reliabilitas, diperoleh data bahwa seluruh item nomor 1, 2, 3, 4 dan 5 adalah reliable atau konsisten. Tabel 4 menjalaskan uji validitas harga (X2). 
Tabel 4. Uji Validitas Harga (X2)

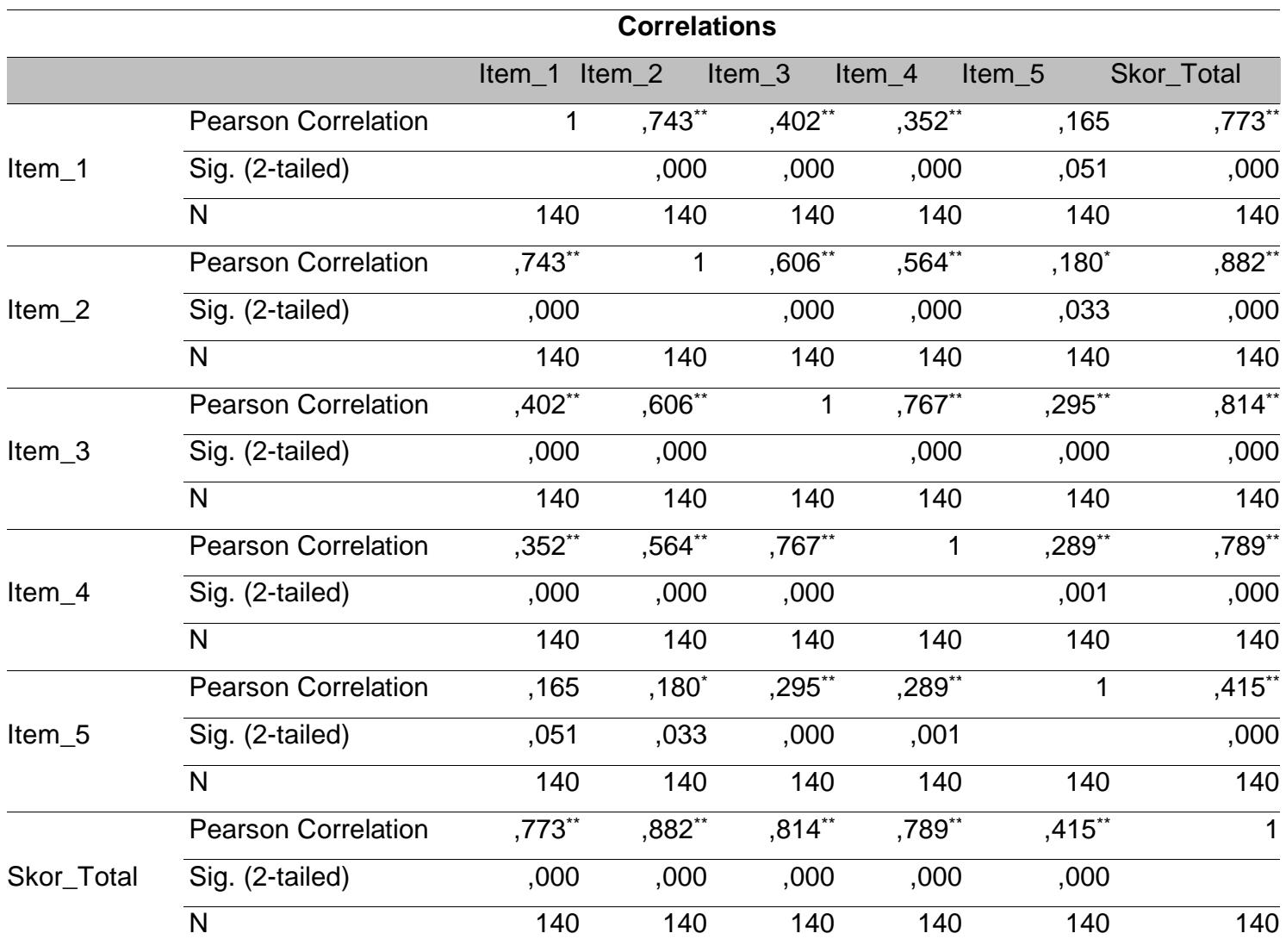

**. Correlation is significant at the 0.01 level (2-tailed).

Sumber: Hasil Pengolahan Data (2020)

Hasil uji reliabilitas harga (X2) dari penelitian ini ditunjukkan pada Tabel 5.

Tabel 5. Uji Reliabilitas Harga (X2)

\begin{tabular}{|c|c|c|c|c|c|c|c|}
\hline & \multicolumn{7}{|c|}{ Item-Total Statistics } \\
\hline & $\begin{array}{l}\text { Scale Mean if } \\
\text { Item Deleted }\end{array}$ & $\begin{array}{l}\text { Scale Variance } \\
\text { Item Deleted }\end{array}$ & $\begin{array}{l}\text { ifCorrected } \\
\text { Correlation }\end{array}$ & $\begin{array}{c}\text { Item-TotalCronbach's } \\
\text { Deleted }\end{array}$ & Alpha & if & Item \\
\hline Item_1 & 15,6 & 4,3 & & ,583 & & & ,772 \\
\hline Item_2 & 15,6 & $3, \varepsilon$ & & ,765 & & & ,701 \\
\hline Item_3 & 15,5 & 4,7 & & ,702 & & & ,734 \\
\hline Item_4 & 15,6 & 4,6 & & 649 & & & ,746 \\
\hline Item_5 & 15,3 & 6,2 & & ,273 & & & ,837 \\
\hline
\end{tabular}

Sumber: Hasil Pengolahan Data (2020)

Berdasarkan tabel 6 dan 7 pada uji validitas dan reliabilitas tentang kepuasan wisatawan $(Y)$, diperoleh data bahwa seluruh item nomor 1, 2, 3, 4 dan 5 adalah valid. Begitu pula pada uji reliabilitas, diperoleh data bahwa seluruh item nomor 1, 2, 3, 4 dan 5 adalah reliable atau konsisten. Tabel 6 menjelaskan uji validitas kepuasan wisatawan. 
Tabel 6. Uji Validitas Kepuasan Wisatawan (Y)

\begin{tabular}{|c|c|c|c|c|c|c|c|}
\hline & \multicolumn{7}{|c|}{ Correlations } \\
\hline & & Item_1 & Item_2 & Item_3 & Item_4 & Item_5 & Skor_Total \\
\hline \multirow{3}{*}{ Item_1 } & Pearson Correlation & 1 & ,319** &, $530^{* *}$ &, $372^{* *}$ &, $632^{* *}$ &, $743^{* *}$ \\
\hline & Sig. (2-tailed) & & ,000 & ,000 & ,000 & ,000 & ,000 \\
\hline & $\mathrm{N}$ & 140 & 140 & 140 & 140 & 140 & 140 \\
\hline \multirow{3}{*}{ Item_2 } & Pearson Correlation & $319^{* *}$ & 1 &, $253^{* *}$ &, $720^{* *}$ &, $302^{* *}$ &, $717^{\star \star}$ \\
\hline & Sig. (2-tailed) &, 000 & & ,003 &, 000 & ,000 &, 000 \\
\hline & $\mathrm{N}$ & 140 & 140 & 140 & 140 & 140 & 140 \\
\hline \multirow{3}{*}{ Item_3 } & Pearson Correlation &, $530^{\star *}$ & ,253 & 1 & $411^{* *}$ & $617^{\star *}$ &, $739^{\star \star}$ \\
\hline & Sig. (2-tailed) & ,000 & ,003 & & ,000 & ,000 &, 000 \\
\hline & $\mathrm{N}$ & 140 & 140 & 140 & 140 & 140 & 140 \\
\hline \multirow{3}{*}{ Item_4 } & Pearson Correlation & $372^{* *}$ &, $720^{\star *}$ & $411^{* *}$ & 1 &, $382^{* *}$ &, $790^{\star \star}$ \\
\hline & Sig. (2-tailed) & ,000 & ,000 & ,000 & & ,000 &, 000 \\
\hline & $\mathrm{N}$ & 140 & 140 & 140 & 140 & 140 & 140 \\
\hline \multirow{3}{*}{ Item_5 } & Pearson Correlation &, $632^{* *}$ &, $302^{* *}$ &, $617^{\star *}$ &, $382^{* *}$ & 1 &, $760^{* *}$ \\
\hline & Sig. (2-tailed) & 000 & ,000 & ,000 & ,000 & &, 000 \\
\hline & $\bar{N}$ & 140 & 140 & 140 & 140 & 140 & 140 \\
\hline \multirow{3}{*}{ Skor_Total } & Pearson Correlation &, $743^{* *}$ &, $717^{\star *}$ &, $739^{* *}$ &, $790^{\star *}$ &, $760^{* *}$ & $\overline{1}$ \\
\hline & Sig. (2-tailed) & ,000 & ,000 & 000 & ,000 & ,000 & \\
\hline & $\bar{N}$ & 140 & 140 & 140 & 140 & 140 & 140 \\
\hline
\end{tabular}

Sumber: Hasil Pengolahan Data (2020)

Uji reliabilitas dari kepuasan wisatawan ditunjukkan pada Tabel 7 sebagai berikut:

Tabel 7. Uji Reliabilitas Kepuasan Wisatawan

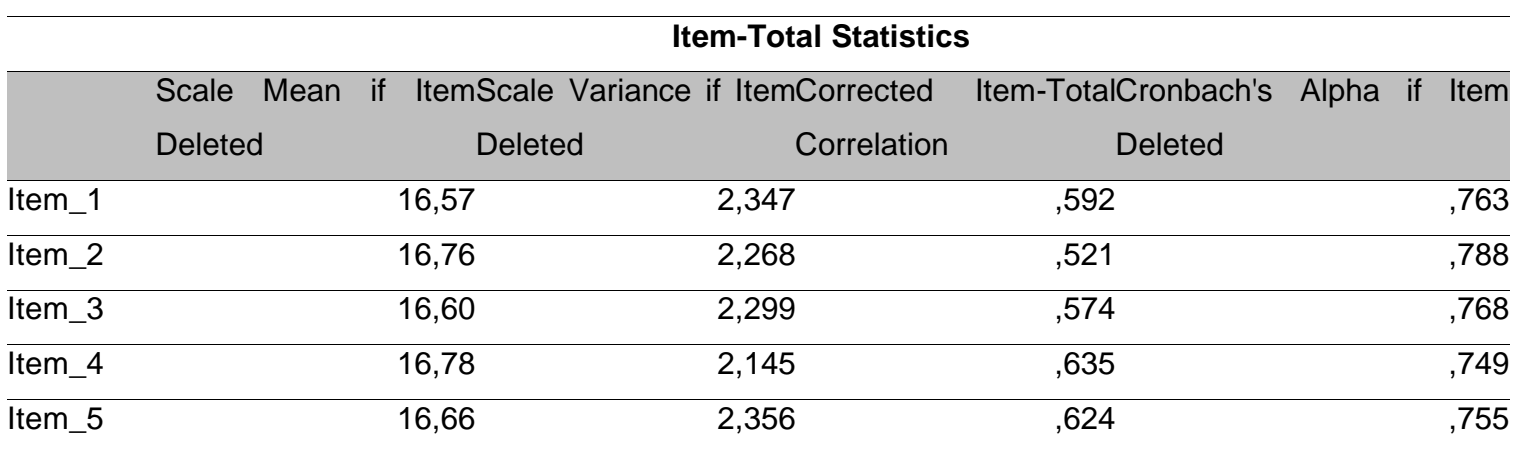

Sumber: Hasil Pengolahan Data (2020)

Berdasarkan tabel 7, diketahui bahwa hipotesis pertama dengan nilai t hitung $(3,811) \geq$ t table $(1,970)$ dan signifikansi hitung $(0,000) \leq$ signifikansi table $(0,05)$. Hal ini dapat diartikan bahwa kualitas pelayanan berpengaruh secara signifikan terhadap kepuasan wisatawan di Kawasan Ekonomi Khusus Tanjung Lesung Kabupaten Pandeglang Provinsi banten. Berdasarkan table 8 , hipotesis kedua dengan nilai $t$ hitung $(8,434) \geq t$ table $(1,970)$ dan signifikansi hitung $(0,000) \leq$ signifikansi table $(0,05)$. Hal ini dapat diartikan bahwa harga 
berpengaruh secara signifikan terhadap kepuasan wisatawan di Kawasan Ekonomi Khusus Tanjung Lesung Kabupaten Pandeglang Provinsi Banten.

Tabel 8 menunjukkan hasil analisa coeficients menggunakan SPSS dari model kualitas pelayanan.

Tabel 8. Coeficients Kualitas Pelayanan

\section{Coefficients $^{\mathrm{a}}$}

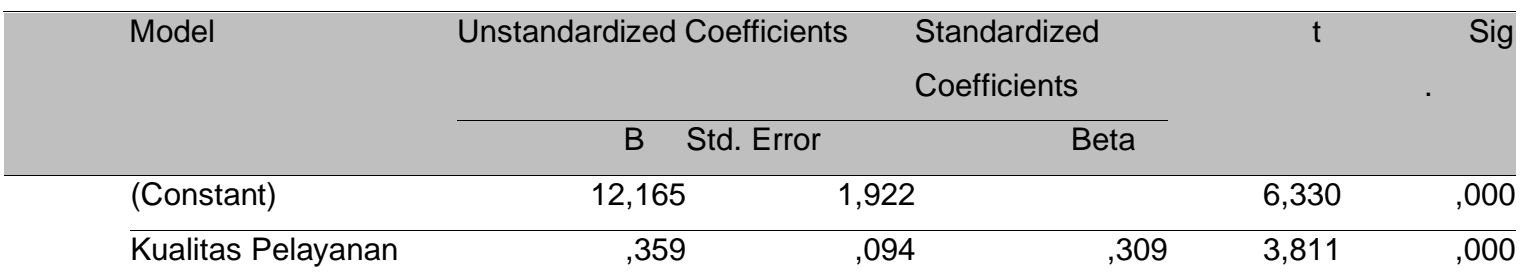

a. Dependent Variable: Kepuasan Wisatawan

Sumber: Hasil Pengolahan Data (2020)

Tabel 9 menunjukkan hasil analisa coeficients menggunakan SPSS dari model harga.

Tabel 9. Coeficients Harga

\begin{tabular}{|c|c|c|c|c|c|}
\hline \multicolumn{6}{|c|}{ Coefficients $^{a}$} \\
\hline \multirow[t]{3}{*}{ Model } & \multirow{2}{*}{\multicolumn{2}{|c|}{ Unstandardized Coefficients }} & Standardized & $\mathrm{t}$ & Sig \\
\hline & & & Coefficients & & \\
\hline & B & Std. Error & Beta & & \\
\hline (Constant) & 11,342 & 1,134 & & 10,006 &, 000 \\
\hline Harga & ,469 & ,056 &, 583 & 8,434 &, 000 \\
\hline
\end{tabular}

a. Dependent Variable: Kepuasan Wisatawan

Sumber: Hasil Pengolahan Data (2020)

Berdasarakan tabel 10, hipotesis ketiga diperoleh nilai uji $F$ hitung $(54,024) \geq F$ tabel $(1,7242)$ dan signifikansi hitung $(0,000) \leq$ signifikansi tabel $(0,05)$. Hal ini dapat diartikan bahwa kualitas pelayanan dan harga sevara bersama-sama berpengaruh secara signifikan terhadap kepuasan wisatawan di Kawasan Ekonomi Khusus Tanjung Lesung Kabupaten Pandeglang Provinsi Banten.

Tabel 10. Uji F

\begin{tabular}{lrrrrr}
\hline \multicolumn{7}{c}{ ANOVA $^{\mathbf{a}}$} & & \\
\hline Model & Sum of Squares & $\mathrm{df}$ & Mean Square & $\mathrm{F}$ & Sig. \\
\hline Regression & 208,356 & 2 & 104,178 & 54,024 & ,000 $^{\text {b }}$ \\
\hline Residual & 264,187 & 137 & 1,928 & & \\
\hline Total & 472,543 & 139 & & &
\end{tabular}

a. Dependent Variable: Kepuasan Wisatawan

b. Predictors: (Constant), Harga, Kualitas Pelayanan

Sumber: Hasil Pengolahan Data (2020)

Berdasarakan Tabel 11 diperoleh nilai $R$ square tentang kualitas pelayanan dan harga terhadap kepuasaan wisatawan sebesar 0,441 yang artinya variabel kualitas pelayanan dan harga berpengaruh terhadap kepuasan wisatawan sebesar $44,10 \%$ dan $55,90 \%$ dipengaruhi oleh variabel lainnya. Tabel 11 menjelaskan model summary. 
Tabel 10. Model Summary

\begin{tabular}{crrrr}
\hline & \multicolumn{4}{c}{ Model Summary } \\
\hline Model & $\mathrm{R}$ & R Square & Adjusted R Square & Std. Error of the Estimate \\
\hline 1 &, $664^{\mathrm{a}}$ &, 441 &, 433 & 1,389
\end{tabular}

a. Predictors: (Constant), Harga, Kualitas Pelayanan

Sumber: Hasil Pengolahan Data (2020)

\subsection{Kualitas Pelayanan terhadap Kepuasan Wisatawan}

Hipotesis pertama dengan nilai t hitung $(3,811) \geq t$ table $(1,970)$ dan signifikansi hitung $(0,000) \leq$ signifikansi table $(0,05)$. Hal ini dapat diartikan bahwa kualitas pelayanan berpengaruh secara signifikan terhadap kepuasan wisatawan di Kawasan Ekonomi Khusus Tanjung Lesung Kabupaten Pandeglang Provinsi banten. Semakin baik kualitas pelayanan, maka semakin meningkat kepuasan wisatawan di Tanjung Lesung.

Daya tarik wisata sebagai indikator utama kualitas pelayanan dibandingkan indikator lainnya seperti fasilitas destinasi dan akksesibilitas menuju destinasi wisata. Sedangkan pemandangan alam resor pantai pasir putih dengan latar belakang gelombang laut dan Anak Gunung Krakatau merupakan indikator utama kepuasan wisatawan dibandingkan indikator lainnya seperti beberapa kali kunjungan wisatawan, keamanan dan keselamatan serta kebersihan dan hygiene.

Penelitian ini mendukung penelitian sebelumnya yang dilakukan oleh (Hau \& Omar, 2014) dengan judul "The Impact of Service Quality on Tourism Satisfaction: The Case Study of Rantau Abang Beach as a Turtle Sanctuary Destination" yang mengatakan ada pengaruh yang signifikan kualitas pelayanan terhadap kepuasan wisatawan. Penelitian ini juga mendukung penelitian sebelumnya yang dialkukan oleh (Al-Ababneh, 2013) dengan judul "Service Quality and its Impact on Tourist Satisfaction" yang mengatakan bahwa terdapat pengaruh kualitas pelayanan terhadap kepuasan wisatawan.

Beberapa dimensi kualitas pelayanan menurut wisatawan mancanegara dan nusantara adalah aksesibilitas menuju daerah tujuan wisata destinasi, fasilitas yang tersedia daerah tujuan wisata dan daya tarik tujuan wisata. Beberapa indikator aksesibilitas terdiri dari: transportasi umum, infrastruktur jalan raya, penerangan jalan raya, rambu-rambu petunjuk arah menuju destinasi wisata dan jaringan internet). Beberapa indikator fasilitas daerah tujuan wisata terdiri dari: kamar hotel, restoran, jasa transportasi jaringan internet dan ATM. Beberapa indikator daya tarik wisata terdiri dari: sejarah, seni budaya, festival, lingkungan (resor pantai, gunung, sungai, flora dan fauna), kelengkapan olahraga dan tempat bermain anak-anak.

\subsection{Harga terhadap Kepuasan Wisatawan}

Hipotesis kedua dengan nilai $t$ hitung $(8,434) \geq t$ table $(1,970)$ dan signifikansi hitung $(0,000) \leq$ signifikansi table $(0,05)$. Hal ini dapat diartikan bahwa harga berpengaruh secara signifikan terhadap kepuasan wisatawan di Kawasan Ekonomi Khusus Tanjung Lesung Kabupaten Pandeglang Provinsi banten. Semakin banyak pilihan tempat-tempat penginapan dan restoran dengan harga yang bervariasi, maka semakin meningkat kepuasan wisatawan 
mancanegara dan nusantara di Kawasan Ekonomi Khusus Tanjung Lesung. Harga kamar hotel sebagai indikator utama dibandingkan indicator lainnya seperti harga food and beverages, harga sewa kelengkapan olahraga dan professional fee for tour guide.

Penelitian ini mendukung penelitian sebelumnya yang dilakukan oleh (Gnanapala, 2015) dengan judul "Tourists Perception and Satisfaction: Implications for Destination Management" yang mengatakan bahwa terdapat pengaruh harga terhadap kepuasan wisatawan di Srilangka. Penelitian ini juga mendukung penelitian sebelumnya yang dilakukan oleh (Somocor, 2017) dengan judul "Tourists Perception and Satisfaction: Implications for Destination Management" yang mengatakan bahwa harga berpengaruh terhadap kepuasan wisatawan di Davao City, Filipina.

Berdasarkan penelitian ini bahwa harga berpengaruh signifikan terhadap kepuasan wisatawan. Harga penginapan kurang dari Rp 500.000 per malam atau "affordable price" lebih banyak diminati wisatawan mancanegara dan nusantara di Kawasan Ekonomi Khusus Tanjung Lesung selama masa pandemic covid-19 sejak Maret hingga Desember 2020 dibandingkan harga penginapan Rp 500.000 - 1.000 .000 per malam dan harga penginapan lebih dari Rp 1.000.000 per malam. Harga yang dibayarkan oleh wisatawan mancanegera dan nusantara antara lain: biaya untuk transportasi umum menuju destinasi wisata, biaya penginapan, biaya makanan dan minuman, biaya sewa kelengkapan wisata, biaya transportasi di sekitar destinasi wisata.

\subsection{Kualitas Pelayanan dan Harga terhadap Kepuasan Wisatawan}

Hipotesis ketiga diperoleh nilai uji $F$ hitung $(54,024) \geq F$ tabel $(1,7242)$ dan signifikansi hitung $(0,000) \leq$ signifikansi tabel $(0,05)$. Hal ini dapat diartikan bahwa kualitas pelayanan dan harga sevara bersama-sama berpengaruh secara signifikan terhadap kepuasan wisatawan di Kawasan Ekonomi Khusus Tanjung Lesung Kabupaten Pandeglang Provinsi Banten. Semakin baik kualitas pelayanan dan harga, maka semakin tinggi tingkat kepuasan wisatawan.

Sedangkan pemandangan alam resor pantai pasir putih dengan latar belakang gelombang laut dan Anak Gunung Krakatau merupakan indikator utama kepuasan wisatawan dibandingkan indikator lainnya seperti beberapa kali kunjungan wisatawan, keamanan dan keselamatan serta kebersihan dan hygiene.

Penelitian ini juga mendukung penelitian sebelumnya yang dilakukan oleh (Azhar et al., 2018) dengan judul "The Role of Marketing Mix and Service Quality on Tourist Satisfaction and Loyalty at Samosir" yang mengatakan bahwa kualitas pelayanan dan harga berpengaruh terhadap kepuasan wisatawan di Davao City, Filipina.

Penelitian ini juga mendukung penelitian sebelumnya yang dilakukan oleh (Somocor, 2017) dengan judul "Tourists Perception and Satisfaction: Implications for Destination Management" yang mengatakan bahwa kualitas pelayanan dan harga berpengaruh terhadap kepuasan wisatawan di Davao City, Filipina. 


\section{Kesimpulan}

Kualitas pelayanan berpengaruh secara signifikan terhadap kepuasan wisatawan di Kawasan Ekonomi Khusus Tanjung Lesung Kabupaten Pandeglang Provinsi banten. Semakin baik kualitas pelayanan, maka semakin meningkat kepuasan wisatawan di Tanjung Lesung. Daya tarik wisata sebagai indikator utama kualitas pelayanan dibandingkan indikator lainnya seperti fasilitas destinasi dan akksesibilitas menuju destinasi wisata. Harga berpengaruh secara signifikan terhadap kepuasan wisatawan di Kawasan Ekonomi Khusus Tanjung Lesung Kabupaten Pandeglang Provinsi banten. Semakin banyak pilihan tempat-tempat penginapan dan restoran dengan harga yang bervariasi, maka semakin meningkat kepuasan wisatawan mancanegara dan nusantara di Kawasan Ekonomi Khusus Tanjung Lesung. Harga kamar hotel sebagai indikator utama dibandingkan indicator lainnya seperti harga food and beverages, harga sewa kelengkapan olahraga dan professional fee for tour guide. Kualitas pelayanan dan harga sevara bersama-sama berpengaruh secara signifikan terhadap kepuasan wisatawan di Kawasan Ekonomi Khusus Tanjung Lesung Kabupaten Pandeglang Provinsi Banten. Semakin baik kualitas pelayanan dan harga, maka semakin tinggi tingkat kepuasan wisatawan. Pemandangan alam resor pantai pasir putih dengan latar belakang gelombang laut dan Anak Gunung Krakatau merupakan indikator utama kepuasan wisatawan dibandingkan indikator lainnya seperti beberapa kali kunjungan wisatawan, keamanan dan keselamatan serta kebersihan dan hygiene.

\section{Daftar Pustaka}

Al-Ababneh, M. (2013). Service Quality and its Impact on Tourist Satisfaction. Interdisciplinary Journal of Contemporary Research in Business, 4(12), 164-177. https://journalarchieves31.webs.com/164-177.pdf

Aliman, N. K., Hashim2, S. M., And, S. D. M. W., \& Harudin1, S. (2016). Tourists'-SatisfactionWith-A-Destination: : An Investigation on Visitors to Langkawi Island. British Journal of Marketing Studies, 4(5), 1-20.

Alves, B., Benavente, J., \& Ferreira, Ó. (2014). Beach Users' Profile, Perceptions and Willingness to Pay for Beach Management in Cadiz (SW Spain). Journal of Coastal Research, 70(1), 521-526. https://doi.org/https://doi.org/10.2112/SI70-088.1

Amyot, J., \& Grant, J. (2014). Environmental Function Analysis. A Decision Support Tool for Integrated Sandy Beach Planning. Ocean \& Coastal Management, 102(Part A), 317-327. https://doi.org/https://doi.org/10.1016/j.ocecoaman.2014.10.009

Azhar, M. E., Jufrizen, J., Prayogi, M. A., \& Sari, M. (2018). The role of marketing mix and service quality on tourist satisfaction and loyalty at Samosir. Revista Hospitalidade, 15(2), 124-137. https://doi.org/10.21714/2179-9164.2018v15n2.007

Dinas Pariwisata Kabupaten Pandeglang. (2020). Wisatawan Asing dan Nusantara di Kabupaten Pandeglang Provinsi Banten. https://pandeglangkab.bps.go.id/

Gnanapala, W. K. A. (2015). Tourists Perception and Satisfaction: Implications for Destination 
Management. American Journal of Marketing Research, 1(1), 7-19. http://www.aiscience.org/journal/ajmrhttp://creativecommons.org/licenses/by-nc/4.0/

Hau, T. C., \& Omar, K. (2014). The Impact of Service Quality on Tourist Satisfaction: The Case Study of Rantau Abang Beach as a Turtle Sanctuary Destination. Mediterranean Journal of Social Sciences, 5(23), 1827-1832. https://doi.org/10.5901/mjss.2014.v5n23p1827

Kotler, P., \& Keller, K. L. (2016). Marketing Management, 15th Edition (P. Kotler \& K. L. Keller (eds.); 15th ed.). Pearson. https://doi.org/10.4236/ait.2017.73004 2,059

Pemerintah Republik Indonesia. (2012). Peraturan Pemerintah Republik Indonesia Nomor 26 Tahun 2012. Pemerintah Republik Indonesia. https://peraturan.bpk.go.id/Home/Details/5238/pp-no-26-tahun-2012

Rahman, A., Chin, Y. H., Haque, R., Pang, A., \& Connie, G. (2011). Customer Satisfaction in Tourism Service Quality. Advanced Science, 4, 3398-3402. https://doi.org/10.4324/9781315858265.ch13

Somocor, M. (2017). Marketing Mix and Service Quality (SERVQUAL) Attributes as Determinants of Customer Satisfaction in Selected Three Star Hotels in Davao City. International Journal of Contemporary Applied Researches, 4(6), 134-188. http://ijcar.net/assets/pdf/Vol4-No6-June2017/13.pdf 